\title{
A Concise Total Synthesis of Naamidine A
}

\author{
Nicholas S. Aberle, Guillaume Lessene and Keith G. Watson* \\ Medicinal Chemistry Group, The Walter and Eliza Hall Institute \\ of Medical Research, Melbourne, Australia
}

\section{SUPPORTING INFORMATION}




\section{General Experimental Procedures.}

All non-aqueous reactions were performed in oven-dried glassware under an atmosphere of dry nitrogen, unless otherwise specified. THF was freshly distilled from sodium/benzophenone under $\mathrm{N}_{2} ; \mathrm{CH}_{2} \mathrm{Cl}_{2}$ and toluene were freshly distilled from $\mathrm{CaH}_{2}$ under $\mathrm{N}_{2}$. Anhydrous acetonitrile (99.8\%) was purchased from Aldrich and used as supplied. All other solvents were reagent grade. Petroleum ether describes a mixture of hexanes in the bp range $40-60{ }^{\circ} \mathrm{C}$. Analytical thin-layer chromatography was performed on Merck silica gel $60 \mathrm{~F}_{254}$ aluminium-backed plates. Flash chromatography was performed with silica gel 60 (particle size 0.040-0.063mm) following the guidelines of Still et al. ${ }^{1}$ All NMR spectra were recorded on a Bruker Avance DRX 300 with the solvents indicated $\left({ }^{1} \mathrm{H}\right.$ NMR at $300 \mathrm{MHz} ;{ }^{13} \mathrm{C}$ NMR at 75 $\mathrm{MHz}$ ). Chemical shifts are reported in $\mathrm{ppm}$ on the $\delta$ scale, referenced to the appropriate solvent peak. Infrared spectra were recorded on a Bruker Tensor27 FT-IR spectrometer. Mass spectrometry was performed on a Finnigan LCQ Advantage MAX. High resolution mass spectra were measured at the University of Canterbury on a Kratos MS80 RFA mass spectrometer. Elemental analyses were carried out for carbon, nitrogen and hydrogen at the University of Otago microanalytical laboratory.

\footnotetext{
${ }^{1}$ Still, W.C.; Kahn, M.; Mitra, A. J. Org. Chem. 1978, 43, 2923.
} 
2-(tert-Butoxycarbonyl-methyl-amino)-3-(4-benzyloxyphenyl)-propionic acid (7).

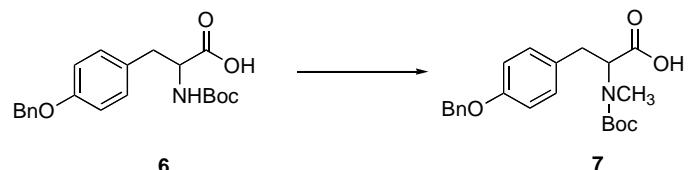

Iodomethane $(5.00 \mathrm{~mL}, 80.32 \mathrm{mmol}, 8.0$ eq.) was added to a solution of BocTyr(Bzl)-OH (6) (3.721 g, $10.02 \mathrm{mmol})$ in THF (30 mL) and cooled to $0{ }^{\circ} \mathrm{C}$. Sodium hydride (60\% dispersion in mineral oil; $1.32 \mathrm{~g}, 33.00 \mathrm{mmol}, 3.3 \mathrm{eq}$ ) was added in small portions over five minutes, during which time hydrogen gas evolved. The solution became a light brown suspension and was removed from the ice-bath after 20 minutes then stirred at room temperature under $\mathrm{N}_{2}$ for 24 hours. Diluting the reaction with EtOAc (50 mL) and quenching by dropwise addition of $\mathrm{H}_{2} \mathrm{O}(50 \mathrm{~mL})$ was followed by removal of the solvent in vacuo. The residue was partitioned between ether (30 mL) and water $(100 \mathrm{~mL})$, and the organic layer was washed with saturated aqueous sodium bicarbonate $(50 \mathrm{~mL})$. The combined aqueous layer was acidified to $\mathrm{pH} 3$ with 5\% citric acid and extracted with EtOAc (3 x $100 \mathrm{~mL})$. The organic extracts were washed with $\mathrm{H}_{2} \mathrm{O}(2 \times 75 \mathrm{~mL}), 5 \% \mathrm{Na}_{2} \mathrm{~S}_{2} \mathrm{O}_{3}(2 \times 50 \mathrm{~mL})$ and $\mathrm{H}_{2} \mathrm{O}(50$ $\mathrm{mL}$ ) then dried $\left(\mathrm{MgSO}_{4}\right)$, filtered and concentrated to give 7 as a pale yellow oil (3.717 g, 96\%) which partially crystallised on standing.

${ }^{1} \mathbf{H}$ NMR ( $\mathrm{CDCl}_{3}, 300 \mathrm{MHz}$, exists as a 1:1 mixture of two rotamers) $\delta$ 7.27-7.42 (m, $5 \mathrm{H}$ ), 7.07-7.12 (m, $2 \mathrm{H}$ ), 6.89 (d, $J=8.4 \mathrm{~Hz}, 2 \mathrm{H}$ ), 5.03 (s, $2 \mathrm{H}$ ), 4.67 and 4.55 (two m, 1 H), 3.22 (m, 1 H), 2.93-3.11 (m, 1 H), 2.73 and 2.66 (two s, 3 H), 1.40 and 1.33 (two s, $9 \mathrm{H}$ ).

IR (ATR, $\mathrm{cm}^{-1}$ ) 2800-3300 (br), 2978, 2935, 1738, 1629, 1369, 1142.

MS (ESI) $384\left(\mathrm{M}-\mathrm{H}^{+}\right), 769\left(2 \mathrm{M}-\mathrm{H}^{+}\right)$.

EA C ${ }_{22} \mathrm{H}_{27} \mathrm{NO}_{5}$ (385.45): Calcd C 68.55, H 7.06, N 3.63; Found C 68.27, H 7.24, N 3.63 . 
tert-Butyl 1-( $N$-methoxy- $N$-methylcarbamoyl)-2-(4-benzyloxy)phenyl)ethylmethylcarbamate (8).

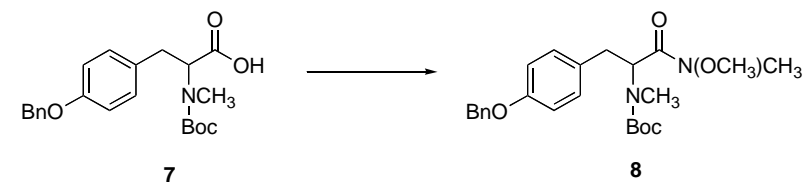

A solution of 7 (3.516 g, $9.12 \mathrm{mmol})$ in $\mathrm{CH}_{2} \mathrm{Cl}_{2}(40 \mathrm{~mL})$ at $0{ }^{\circ} \mathrm{C}$ was treated with DIEA (2.40 mL, $13.78 \mathrm{mmol})$ then DAST (0.77 mL, $10.89 \mathrm{mmol})$. Stirring continued at $0{ }^{\circ} \mathrm{C}$ for 15 minutes before addition of a second solution prepared thus: $\mathrm{N}, \mathrm{O}-$ dimethylhydroxylamine $(1.340 \mathrm{~g}, 13.737 \mathrm{mmol})$ in $\mathrm{CH}_{2} \mathrm{Cl}_{2}(20 \mathrm{~mL})$ at $0{ }^{\circ} \mathrm{C}$ was treated with DIEA (3.54 mL, $20.954 \mathrm{mmol}$ ) by dropwise addition and stirred for 15 minutes. The combined solution was then stirred for a further 15 minutes at $0{ }^{\circ} \mathrm{C}$ followed by $3 \mathrm{~h}$ at room temperature, whereupon it was washed successively with 40 $\mathrm{mL}$ of saturated aqueous solutions of sodium bicarbonate, ammonium chloride and sodium chloride. The organic layer was dried $\left(\mathrm{MgSO}_{4}\right)$, filtered and concentrated in vacuo to a crude orange oil. Purification by flash chromatography $\left(100 \% \mathrm{CH}_{2} \mathrm{Cl}_{2}\right.$ to $90 \% \mathrm{CH}_{2} \mathrm{Cl}_{2}$ in methanol) afforded 8 as a colourless oil (3.36 g, 86\%).

${ }^{\mathbf{1}} \mathbf{H}$ NMR (DMSO-d 6 , $300 \mathrm{MHz}, 360 \mathrm{~K}$; exists as a complex mixture of four rotamers at room temperature) $\delta 7.25-7.40(\mathrm{~m}, 5 \mathrm{H}), 7.08(\mathrm{~d}, J=8.6 \mathrm{~Hz}, 2 \mathrm{H}), 6.89$ (d, $J=8.6$ Hz, 2 H), 5.13 (bs, 1 H), 5.04 (s, 2 H), 3.59 (s, 3 H), 3.08 (s, 3 H), 2.75-2.95 (m, 2 H), 2.71 (s, $3 \mathrm{H}), 1.25$ (s, $9 \mathrm{H})$.

${ }^{13}$ C NMR (DMSO-d $\left.\mathrm{d}_{6}, 300 \mathrm{MHz}, 360 \mathrm{~K}\right) \delta$ 170.6, 157.3, 154.7, 137.5, 130.3, 130.1, 128.4, 127.7, 127.4, 115.0, 79.0, 69.8, 61.2, 56.2, 33.7, 32.4, 29.9, 28.0.

IR (ATR, $\mathrm{cm}^{-1}$ ) 2976, 2931, 1674, 1665, 1511, 1391, 1240, 1173, 696, 495.

HRMS (ESI) Calcd for $\left(\mathrm{M}+\mathrm{H}^{+}\right) \mathrm{C}_{24} \mathrm{H}_{33} \mathrm{~N}_{2} \mathrm{O}_{5}{ }^{+}$429.2389, found 429.2382. 
tert-Butyl 1-(4-(benzyloxy)phenyl)-4-(4-methoxyphenyl)-3-oxobutan-2-yl methyl carbamate (9).

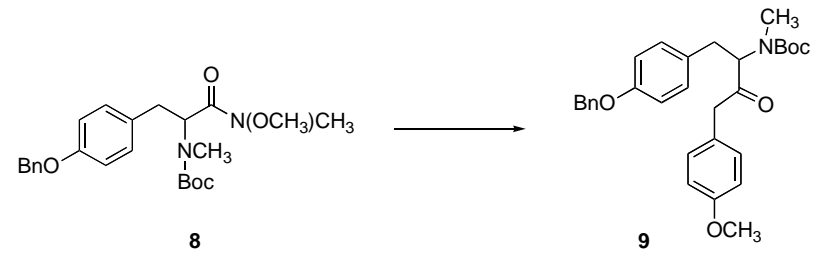

A solution of Weinreb amide $8(2.911 \mathrm{~g}, 6.790 \mathrm{mmol})$ in THF $(27 \mathrm{~mL})$ at $0{ }^{\circ} \mathrm{C}$ was treated dropwise over five minutes with 4-methoxybenzylmagnesium chloride $(0.20$ $\mathrm{M}$ in THF; $50 \mathrm{~mL} ; 10 \mathrm{mmol}$ ). Stirring continued at $0{ }^{\circ} \mathrm{C}$ for $10 \mathrm{~min}$ then for $3 \mathrm{~h}$ at room temperature. Quenching the reaction with saturated aqueous ammonium chloride (30 mL) was tempered by an ice bath. Resulting solids were dissolved with water $(20 \mathrm{~mL})$, the phases separated and the aqueous layer was extracted with diethyl ether ( 3 x $50 \mathrm{~mL})$. The combined organic layers were washed with brine $(75 \mathrm{~mL})$ then dried $\left(\mathrm{Na}_{2} \mathrm{SO}_{4}\right)$, filtered and concentrated to give a clear residue which was purified by flash chromatography (4:1 petroleum ether:EtOAc). 9 was obtained as a clear oil which crystallised on standing (2.071 g, 62\%).

${ }^{1} \mathbf{H}$ NMR $\left(\mathrm{CDCl}_{3}, 300 \mathrm{MHz}\right.$, exists as a 1:1 mixture of 2 rotamers) $\delta$ 7.28-7.41 (m, 5 H), 6.97-7.08 (m, 4 H), 6.80-6.85 (m, 4 H), 5.00 (s, 2 H), 4.72 and 4.30 (two m, $1 \mathrm{H}$ ), 3.77 (s, 3 H), 3.66 (s, 2 H), 3.09 (m, 1 H), 2.79 (m, 1 H), 2.57 and 2.51 (two s, 3 H), 1.41 and 1.33 (two s, $9 \mathrm{H}$ ).

${ }^{13} \mathbf{C}$ NMR $\left(\mathrm{CDCl}_{3}, 300 \mathrm{MHz}\right.$, exists as a 1:1 mixture of 2 rotamers) $\delta 205.7$ and 205.4, 158.7 and 158.5, 157.5 and 157.3, 155.7, 154.8, 137.0, 130.3, 130.2, 130.0, 128.5, 127.8, 127.3, 125.7 and 125.6, 114.9 and 114.7, 114.1 and 114.0, 80.8 and 80.2, 70.0, 66.5, 64.5, 55.2, 46.1 and 45.7, 32.8, 32.4 and 32.1, 28.3 and 28.1.

IR (ATR, cm $\left.{ }^{-1}\right)$ 2969, 2935, 1726, 1672, 1510, 1239, 1162.

MS (ESI) $512\left(\mathrm{M}+\mathrm{Na}^{+}\right)$.

EA C ${ }_{30} \mathrm{H}_{35} \mathrm{NO}_{5}$ (489.60): Calcd C 73.59, H 7.21, N 2.86; Found C 73.40, H 7.40, N 2.89 . 


\section{Naamine A (10).}

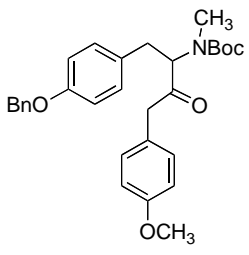

9

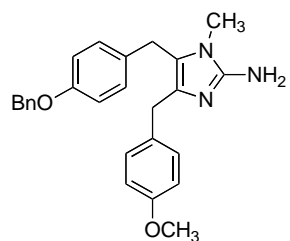

O-Bn-10

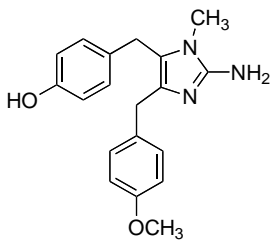

10

Aminoketone 9 (695 mg, $1.42 \mathrm{mmol}$ ) was dissolved in $4 \mathrm{M} \mathrm{HCl}$ in diethyl ether (28 $\mathrm{mL}$ ) and allowed to stand in a stoppered flask for 1 hour. Evaporation of the solvent followed by suspension in ether resulted in formation of a white powder which was collected by filtration. The filtrate was concentrated to dryness and suspended again in ether to produce further solids. The combined precipitate was washed with ether and dried in vacuo.

The $\mathrm{HCl}$ salt was suspended in $\mathrm{H}_{2} \mathrm{O}(30 \mathrm{~mL})$. Cyanamide was added in one portion and the reaction stirred at $90{ }^{\circ} \mathrm{C}$ for $1 \mathrm{~h}$, becoming a homogeneous pale yellow solution upon heating. An off-white precipitate formed as the flask cooled, and the mixture was made basic to $\mathrm{pH} 10$ with $0.3 \mathrm{M}$ aqueous $\mathrm{NaOH}$. The solids were collected by filtration and dried in vacuo, affording the desired tri-substituted 2aminoimidazole O-Bn-10 (488 mg, 86\%).

${ }^{1} \mathbf{H}$ NMR $\left(\mathrm{CDCl}_{3}, 300 \mathrm{MHz}\right) \delta$ 7.28-7.43 (m, $\left.5 \mathrm{H}\right), 7.14$ (d, $\left.J=8.6 \mathrm{~Hz}, 2 \mathrm{H}\right), 6.96$ (d, $J=8.6 \mathrm{~Hz}, 2 \mathrm{H}), 6.85$ (d, $J=8.6 \mathrm{~Hz}, 2 \mathrm{H}), 6.77$ (d, $J=8.6 \mathrm{~Hz}, 2 \mathrm{H}), 5.01(\mathrm{~s}, 2 \mathrm{H})$, 3.84 (s, 2 H), 3.74 (s, 5 H), 3.05 (s, 3 H).

${ }^{13} \mathrm{C}$ NMR $\left(\mathrm{CDCl}_{3}, 300 \mathrm{MHz}\right) \delta 157.6,157.1,146.5,136.6,132.2,131.1,130.4$, 129.1, 128.5, 128.2, 127.6, 127.1, 120.7, 114.7, 113.5, 69.7, 54.9, 31.7, 29.0, 28.2.

IR (ATR, $\mathrm{cm}^{-1}$ ) 3382, 3117, 2904, 1644, 1611, 1509, 1247, 810, 737.

MS (ESI) $414\left(\mathrm{M}+\mathrm{H}^{+}\right), 827\left(2 \mathrm{M}+\mathrm{H}^{+}\right)$.

EA C ${ }_{26} \mathrm{H}_{27} \mathrm{~N}_{3} \mathrm{O}_{2}$ (413.51): Calcd C 75.52, H 6.58, N 10.16; Found C 75.33, H 6.46, N 10.39 .

A flask containing a suspension of benzyl ether $\mathbf{O}-\mathbf{B n - 1 0}$ as obtained above (68 mg, $0.16 \mathrm{mmol})$ and Pd/C (10 wt. \%; $9 \mathrm{mg})$ in methanol (4 mL) was stirred under $\mathrm{H}_{2}$ until all starting material was consumed (monitored by MS). The suspension was 
filtered through a plug of celite and washed with methanol. Evaporation of the filtrate afforded naamine A (10) (53 mg, 100\%) as a partially crystalline solid.

${ }^{1} \mathbf{H}$ NMR (MeOD, $\left.300 \mathrm{MHz}\right) \delta 7.07$ (d, $J=8.6 \mathrm{~Hz}, 2 \mathrm{H}$ ), 6,83 (d, $J=8.5 \mathrm{~Hz}, 2 \mathrm{H}$ ), 6.75 (d, $J=8.6 \mathrm{~Hz}, 2 \mathrm{H}), 6.63$ (d, $J=8.5 \mathrm{~Hz}, 2 \mathrm{H}), 3.75$ (s, $2 \mathrm{H}), 3.71$ (s, $3 \mathrm{H}), 3.68$ (s, $2 \mathrm{H}), 3.07$ (s, $3 \mathrm{H})$.

${ }^{13}$ C NMR (DMSO-d $\left.\mathrm{d}_{6}, 300 \mathrm{MHz}\right) \delta 157.2,155.5,148.3,133.8,131.6,129.9,129.5$, 128.9, 119.8, 115.1, 113.4, 55.0, 32.0, 28.8, 27.9.

IR (ATR, cm ${ }^{-1}$ ) 3322, 2913, 2362, 1633, 1609, 1508, 1242, 813.

HRMS (ESI) Calcd for $\left(\mathrm{M}+\mathrm{H}^{+}\right) \mathrm{C}_{19} \mathrm{H}_{22} \mathrm{~N}_{3} \mathrm{O}_{2}{ }^{+}$324.1712, found 324.1713. 


\section{Naamidine A (1).}

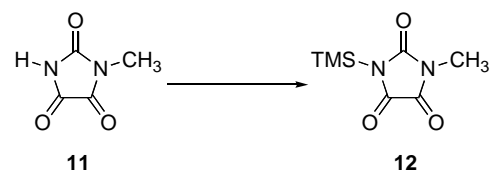

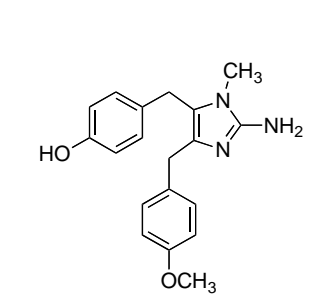

10
12

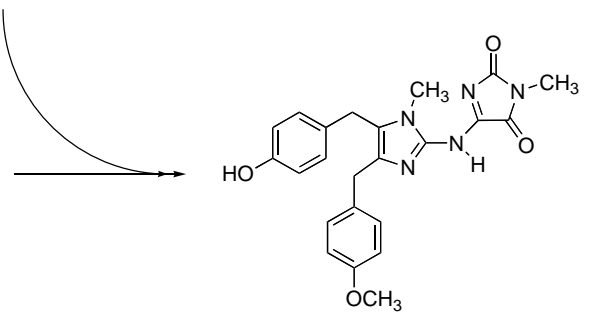

1

1-methylparabanic acid 11 (105 mg, $0.820 \mathrm{mmol})$ in acetonitrile (750 $\mu \mathrm{L})$ was treated with $N, O$-bis(trimethylsilyl)acetamide $(253 \mu \mathrm{L}, 1.02 \mathrm{mmol})$ and stirred at reflux for $45 \mathrm{~min}$. The yellow solution was concentrated to dryness under vacuum, opened to dry $\mathrm{N}_{2}$ to minimise exposure to air of the silylated product $\mathbf{1 2}$. The residue was taken in toluene $(1.30 \mathrm{~mL})$ and added to $\mathbf{1 0}(53 \mathrm{mg}, 0.16 \mathrm{mmol})$. The mixture was stirred overnight at reflux then diluted with EtOAc $(15 \mathrm{~mL})$ and washed with $\mathrm{H}_{2} \mathrm{O}$. The organic layer was dried over $\mathrm{Na}_{2} \mathrm{SO}_{4}$ and concentrated to dryness. Purification by flash chromatography (85:15 toluene:methanol with $1 \% \mathrm{NEt}_{3}$ ) provided naamidine A (1) as a yellow powder (57 mg, 80\%).

${ }^{1} \mathbf{H}$ NMR $\left(\mathrm{CDCl}_{3}, 300 \mathrm{MHz}\right) \delta 7.09(\mathrm{~d}, J=8.6 \mathrm{~Hz}, 2 \mathrm{H}), 6.78-6.82(\mathrm{~m}, 4 \mathrm{H}), 6.72(\mathrm{~d}$, $J=8.6$ Hz, 2 H), 3.86 (s, 2 H), 3.85 (s, 2 H), 3.76 (s, 3 H), 3.35 (s, 3 H), 3.15 (s, 3 H). ${ }^{13} \mathrm{C}$ NMR $\left(\mathrm{CDCl}_{3}, 300 \mathrm{MHz}\right) \delta$ 162.3, 158.0, 155.8, 154.9, 145.9, 144.5, 133.3, 130.2, 128.7, 127.8, 127.4, 126.8, 115.5, 113.8, 54.9, 31.0, 29.6, 28.2, 24.5.

IR (ATR, cm ${ }^{-1}$ ) 3308, 2949, 2907, 2832, 1786, 1707, 1563, 1440, 1242, 1143, 606. MS (ESI) $434\left(\mathrm{M}+\mathrm{H}^{+}\right)$.

EA C ${ }_{23} \mathrm{H}_{23} \mathrm{~N}_{5} \mathrm{O}_{4}$ (433.46): Calcd C 63.73, H 5.35, N 16.16; Found C 63.63, H 5.31, N 16.03 . 


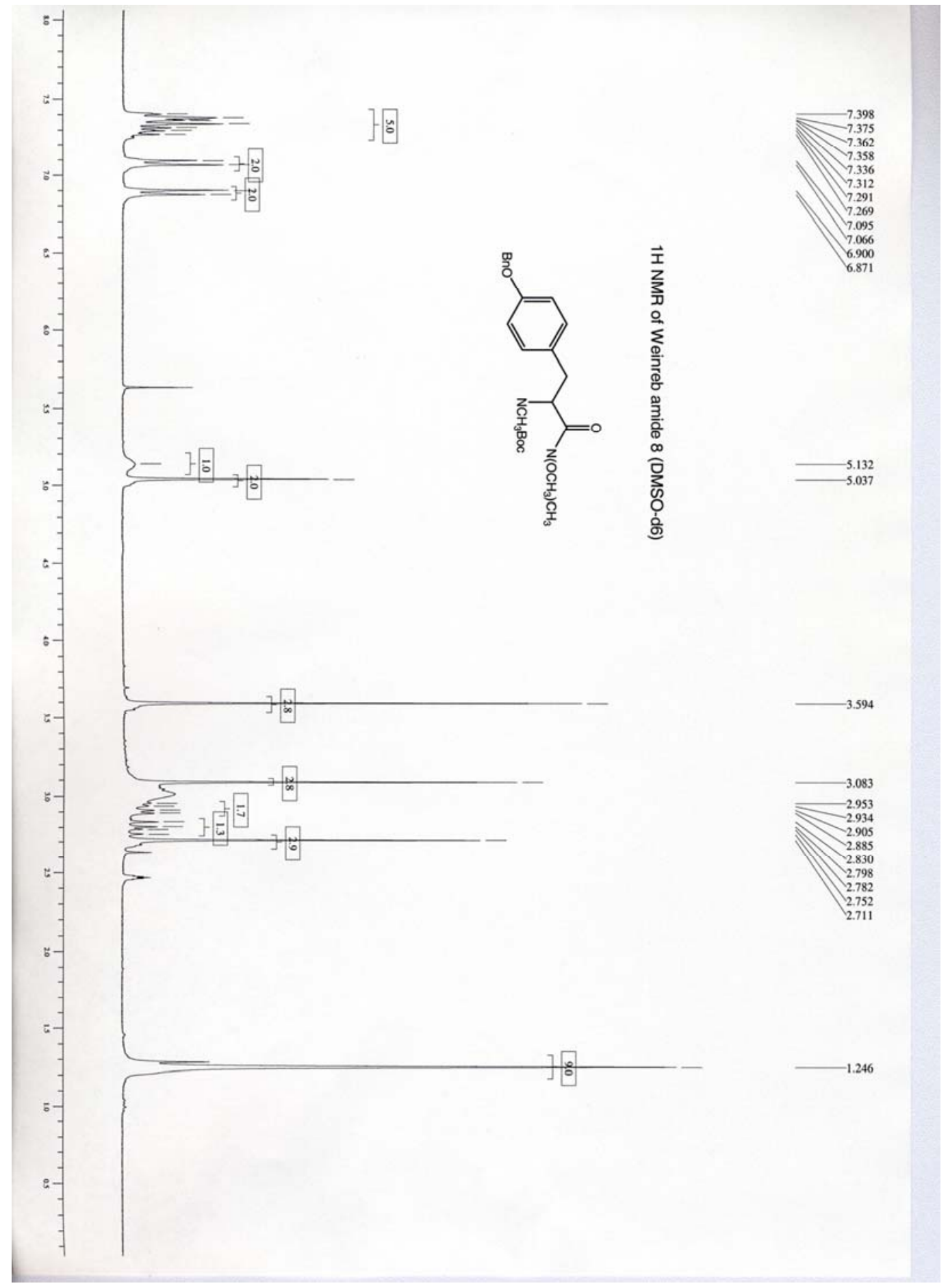




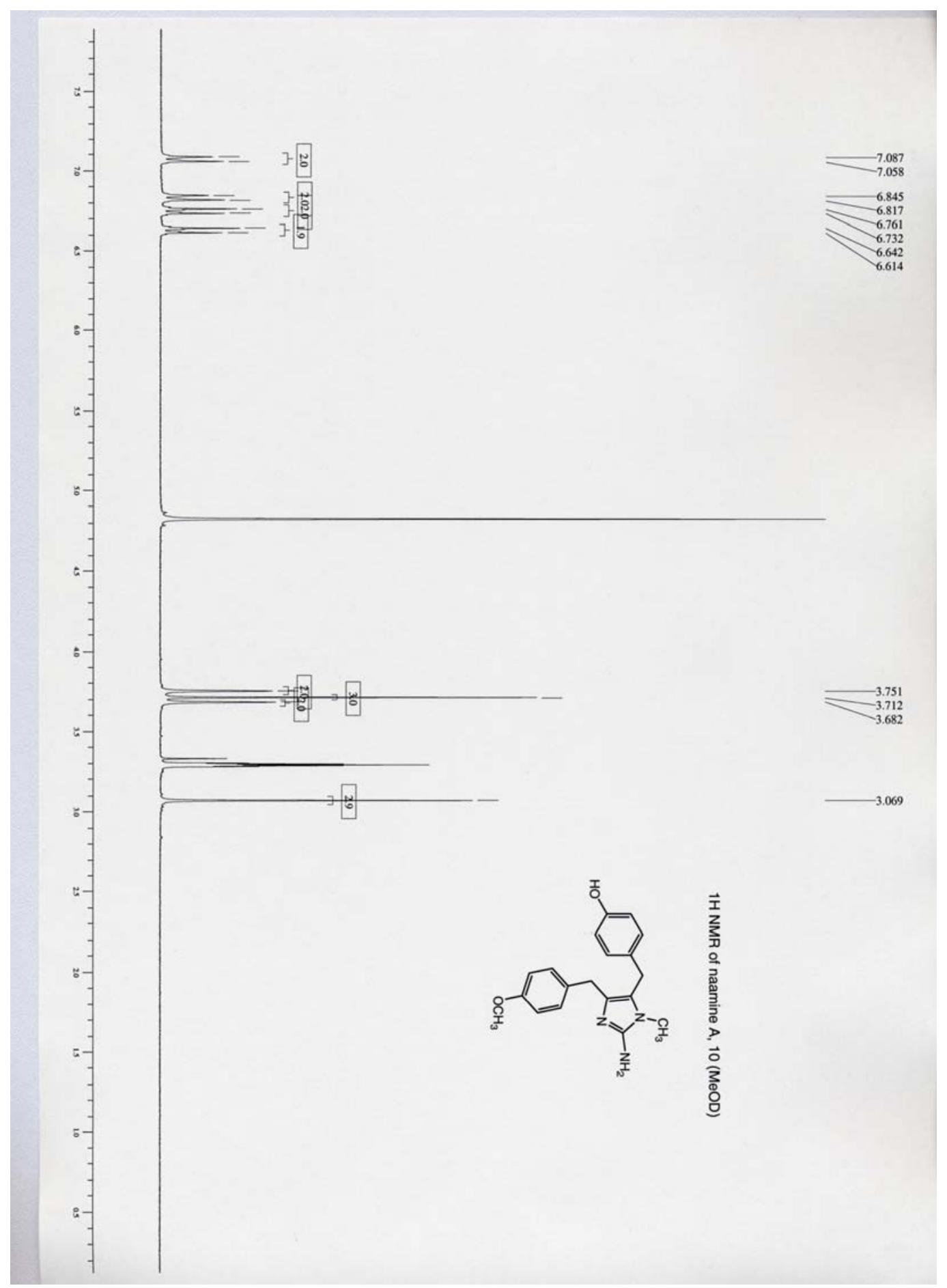




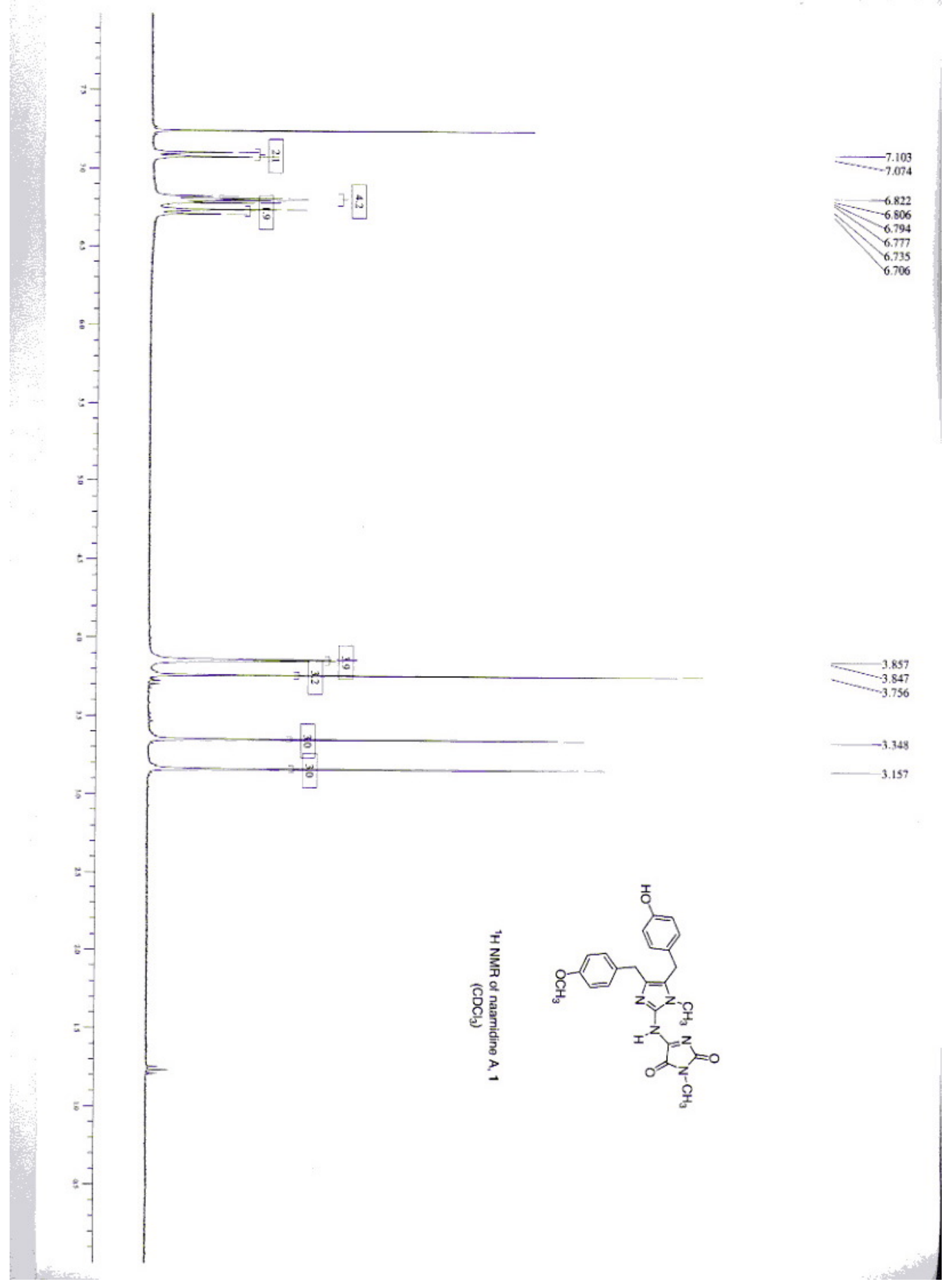

